\title{
Microclimatic Behavior of Sustainable Urban Schemes Proposed for Hillside Areas versus Existing Neighborhoods in the Metropolitan Area of Mendoza, Argentina
}

\author{
Ana CastilloA*, Erica CorreaA, María Cantón ${ }^{\mathrm{A}}$ \\ Received: January 25, 2021 | Revised: October 03, 2021 | Accepted: October 05, 2021 \\ doi: 10.5937/gp25-30532
}

\begin{abstract}
The Metropolitan Area of Mendoza (MMA), Argentina, has extended towards peripheral hillside areas without considering the environmental impact of this action. This growth has continued the urban model of flatland development, causing changes in the ecosystem and an increase in outdoor air temperature. This work proposes and evaluates urban schemes that incorporate design criteria with the objective of preserving environmental characteristics and mitigating the effect of urbanization on the microclimate. The proposed grid layouts, located in three predominant slopes, were linear organic and Cul-de-Sac. Methodologically, the microclimatic response of the proposed schemes was evaluated by applying ENVI-met software simulation. The results show that urban growth is possible when carefully considering environmental limitations which grant maximum air temperature reductions of up to $2^{\circ} \mathrm{C}$.
\end{abstract}

Keywords: Sustainable Urban Development; Hillside; Urban Land; Microclimatic Simulation; Mendoza; ENVI-met.

\section{Introduction}

The growth of Latin American cities has shown late transformations compared to more developed parts of the world (USA and Europe) (Castells, 2017). Until 1925, the level of urbanization in Latin America was lower than more developed regions, but during the next fifty years, the urbanization of this region accelerated notably (UN, 2016). Rapid urbanization was closely linked to high population growth with a net redistribution of the population from rural to urban areas. However, this growth steadily decreased after the 1970s due to the high rate of population moving to the outskirts of the city (da Cunha et al., 2009).

The microclimate of cities is modified by the intense anthropization of natural environments causing urban temperatures to be significantly higher than suburban or rural ones (Zhou et al., 2017). This originates two phenomena known as Urban Heat Island -UHI- and Urban Warming -UW-. Urban microclimate plays an important role not only in the energy consumption of buildings and the feeling of comfort and habitability of outdoor spaces but also in air pollution, health and the quality of life of urban areas. During the last years, intense research has been carried out to develop, test and implement efficient technologies for the mitigation of urban warming, considering the climatic and geomorphological characteristics of the implantation site. (Doulos et al., 2004; Synnefa et al., 2008; 2012; Zinzi \& Agnoli, 2012; Correa et

\footnotetext{
A Instituto de Ambiente, Hábitat y Energía (INAHE). CONICET Argentina. Av. Ruiz Leal s/n, San Martin Park, Mendoza, Argentina. alcastillo@mendoza-conicet.gob.ar; ecorrea@mendoza-conicet.gob.ar; macanton@mendoza-conicet.gob.ar

* Corresponding author: Ana Castillo, e-mail: alcastillo@mendoza-conicet.gob.ar
} 
al., 2012; Alchapar \& Correa, 2015; Sosa et al., 2018, Logaraj Ramakreshnan et al., 2018). This has fundamentally led to the use of cold materials characterized by their high solar reflectance and infrared emissivity, which can reduce the absorption of solar radiation when used in ceilings and pavements (Wang \& Akbari, 2016). The incorporation of urban green spaces with an adequate design, green roofs and permeable materials is capable of promoting the reduction of heat due to their effects on evapotranspiration processes. Moreover, the addition of urban forest produces shade and improves the convective and radiative cooling processes into the city's structure (Gill et al., 2007; Synnefa et al., 2012; Wang \& Akbari, 2016; Zinzi et al., 2012; Santamouris, 2016). Finally, adequate urban planning can also play a vital role in mitigating the UHI effect due to its influence on shape and orientation in the thermal performance of urban fabric (Yamamoto, 2006; Middel, et al., 2014, 2015; Salvatti et al., 2018; Palme et al., 2017).

Most technologies are usually implemented in largescale urban rehabilitation projects. Based on the results, the application of the different strategies can reduce air temperatures between 1 and $4{ }^{\circ} \mathrm{C}$, cooling loads between 18 and 93\%, and electricity demand during peak hours between 11 and 27\%. It can also improve the internal comfort conditions by reducing discomfort hours between 9 and $10 \%$ and reduce equivalent annual carbon dioxide emissions (Akbari et al., 2009).

The urban development of the Metropolitan Area of Mendoza (MMA), Argentina, has spread to the periphery, in this case to Mendoza's hillside area, $32.5^{\circ}$ $\mathrm{S}$ latitude and $68.5^{\circ} \mathrm{W}$ longitude. It is a narrow $15 / 20$ $\mathrm{km}$ wide strip which extends between the eastern mountains' slopes and the plain, between $800 \mathrm{~m}$ a.s.l. and $1500 \mathrm{~m}$ a.s.l approximately. This growth model has generated anthropic pressure on the territory since it has kept typical urban models with homogeneous settlement patterns found in consolidated areas of the city. This has caused a change in the territory's morphology and landscape generating changes in the natural context on which the urban fabric is based (Haller, 2017; Moschella, 2017; Abraham, 1990). In the case of the piedmont area, this urban expansion has produced a high impact since sectors with high environmental fragility that also act as buffers have been urbanized (Lopez Rodriguez, 2008). Among the environmental impacts caused by urban growth is a higher alluvial risk due to the increase in impervious surfaces and deforestation. This brings about the loss of natural soil and its biodiversity, the sealing of land, and the increase in air pollution and noise, all of which favour the modification of the city's temperature and wind profiles. From the microclimatic point of view, the hillside area has conditions of arid- ity, high solar radiation, and scarce water resources. According to Correa (2006), this determines the appearance of an urban heat island located in the piedmont area of MMA. This phenomenon could be explained by the excessive hillside urbanization which, coupled with the thermal properties of local materials -mainly stone-, has favoured the increase of thermal inertia. Thus, the cooling period of this area has extended into the early morning hours, generating a hot spot with temperatures up to $9^{\circ} \mathrm{C}$ higher compared to its periphery (Correa et al., 2006).

The consequences of this urban development raise the need to rethink the urban scheme to respond to the morphological characteristics of the land and mitigate the increase in air temperature. The Institute of Environment, Habitat and Energy (INAHE), Mendoza, Argentina carries out research related to sustainable urban development based on bioclimatic design. The present work employs microclimate monitoring analysis and modelling through Computational Fluid Dynamics (CFD) simulations to evaluate the impact of different variables and urban characteristics over the thermal performance of a city's sector. These studies have contributed to studying the effect of urbanization on the microclimate by means of two techniques: a) observational approaches: field measurements, remote sensing from GIS tools; and b) simulation approaches: energy balance models or numerical studies using CFD (Mirzaei \& Haghighat, 2010). The main advantage of simulation studies over observational ones is the possibility to perform comparative analyses based on different scenarios. Urban microclimate CFD software varies substantially depending on its physical basis, spatial-temporal resolution, and output variables (Allegrini, et al., 2015). The most widely used both nationally and internationally are Envi-MET met (Crank et al., 2018; Maggiotto, 2021), Energy-Plus (Kuo-Tsang \& Yi-Jhen, 2017; Yang et al., 2012), SOLENE-Microclimate (Merlier et al., 2019; Morille et al., 2015), TRNSYS (Palme \& Salvati, 2018; Perini et al., 2017), and SIMEDIF (Boutet et al., 2016; Ruiz \& Correa, 2015), among others.

The ENVI-met simulation software model developed by Michael Bruse (Bruse \& Fleer, 1998a) is one of the most widely employed dynamic simulation tools for microclimate analysis. The review conducted by Tsoka et al., (2018) points out that up until 2017 more than 1900 registered users worldwide have used it for microclimate research. Besides this, the fact that $77 \%$ of the total number of ENVI-met studies have been published during the last five years evidences the software's current validity. In the majority of the existing studies, the model has been applied not only to investigate current microclimatic conditions but also to compare performance assessment of various mitigation strate- 
gies considering the UHI effect. This is why the ENVImet model has been applied in this investigation. In addition; it has been applied in different regions around the world, for example, $66,5 \%$ of researches have been performed in Europe and Asia while only 5.1\% in Latin America. Regarding the evaluated climate conditions, only $13.2 \%$ of the studies correspond to BWh according to Köppen classification. Hence, this study will contribute to broaden the scientific data related to Latin American cities in arid climates.
The present study aims at assessing the micro-climatic performance of different urbanization schemes in order to determine the best options to reduce urban warming, take advantage of the solar resource and mitigate natural hazards of the piedmont. In their design, these schemes incorporate criteria and strategies to avoid natural disasters in hillside regions, such as avalanches, mud-flows and desertification. The ultimate goal is to contribute to the sustainable development of the hillside area.

\section{Data and Methods}

In order to compare the prevailing urban development model in the hillside area with sustainable urbanization schemes adapted to the insertion context, the following methodology was undertaken: a) characterization of study area b) characterization of case study, c) scheme evaluation method based on simulations using ENVI-met software, and d) adjustment of thermal behaviour results between the simulated model and the microclimatic measurements in an existing and representative urban scheme in the hillside of MMA.

\section{Characterization of the study area}

The metropolitan area of Mendoza is located in the central-western region of Argentina with a surface area of $368 \mathrm{~km}^{2}$ and an approximate population of $1,086,000$. The city's climate is semi-desertic corresponding to BWk in the Köppen classification. The principal climatic condition is cold steppe/desert (Kottek et al., 2006), with relatively low atmospheric humidity percentage (45\%), $218 \mathrm{~mm}$ of annual rainfall, high heliophany, and a maximum daily solar radiation average of $1022 \mathrm{~W} / \mathrm{m} 2$ in summer (weather underground, n.d.). The annual average temperature is $16.50^{\circ} \mathrm{C}$, with $24.50^{\circ} \mathrm{C}$ average high and $9.60^{\circ} \mathrm{C}$ average low (Mendoza Aero Observations, 2014).

The urban structure of MMA shows the same growth patterns of intermediate Latin American cities: discontinuous, dispersed and low-density. This

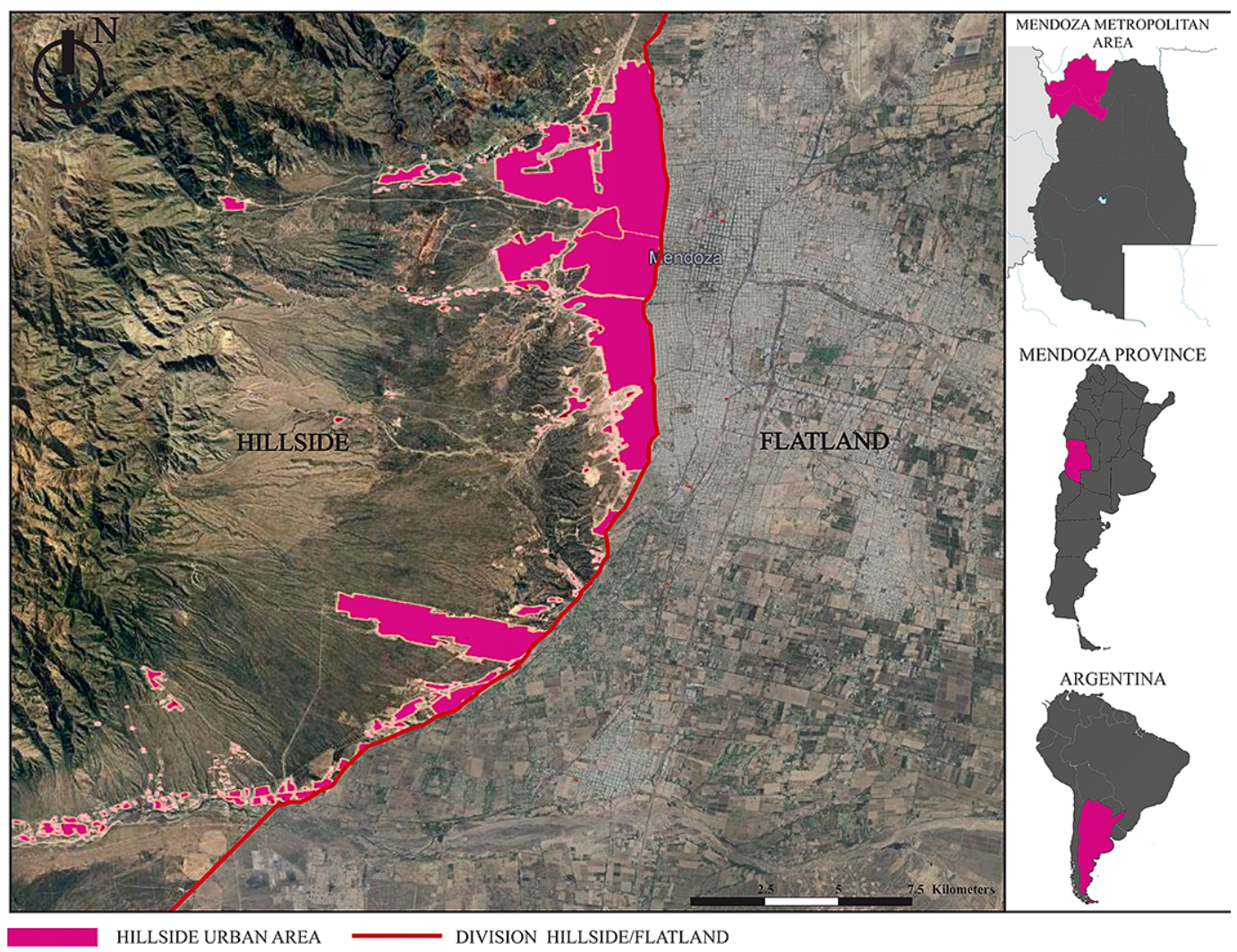

Figure 1. Location of the case study in the South American context and its expansion into the piedmont of MMA 
spread arises due to the need for developable lands associated to the increase of population and the search for areas with higher environmental quality in the periphery. (Mesa \& Giusso, 2014). The expansive development process has generated an excessive urbanization of the periphery towards both the east-south sector on agricultural lands and towards the west sector on piedmont areas.

The hillside study area, located in the western sector of MMA, constitutes an extensive geomorphological unit of $20-15 \mathrm{~km}$ wide that connects the eastern front of the Andes foothills with Mendoza City (Gómez et al., 2017). It is characterized by its 10 to $30 \%$ steep west-east slope and the existence of various temporary water courses. It has scarce and degraded vegetation of the shrub type of Larrea sp. (jarillales) and hard grasses. The area's soils are not consolidated and are feasible to suffer accelerated erosion processes, mainly by water. From the climatic point of view, the arid condition prevails due to the scarcity of water resources (Abraham, 1990).

During the late 20th century, urbanization processes in the piedmont area accelerated with the occurrence of the first informal urbanizations and were later intensified by state and private neighbourhood planning (Abraham, 2005). Its urban development is in line with that of the city in the flatland, that is, a predominant rational checkerboard grid scheme with forested avenues whose orientation accompany the maximum slope (West - East), incorporating forestry which is not adapted to the insertion site. The urbanized area $(6,800 \mathrm{Ha})$ of the foothill sector of the MMA can be observed in Figure 1.

A field survey revealed that the urbanizations in the hillside area present the following characteristics: low-density dwellings with average height ranging between 4 and $9 \mathrm{~m}$, road channels with a vegetation scheme aligned with second-magnitude species -species between 10 and $15 \mathrm{~m}$ high, such as Morus albarepresenting $42 \%$ of the trees used in road channels in the MMA, and the Melia azedarach species, which represents $18 \%$ of the afforestation in the MMA. Regarding the materiality of the elements of the urban canyons, they are characterized by: paved streets; red, yellow and grey mosaic sidewalks; flat roofs with aluminum coated membranes and plastered facades painted in various light tones.

\section{Characterization of an existing urban scheme}

A cartographic analysis of the sector was carried out to select an urban scheme representative of the current situation of this urban hillside development. This allowed the identification of a characteristic residential group of the dominant scheme in the piedmont area ( $80 \%$ of the rational morphology grid) (Figure 2).

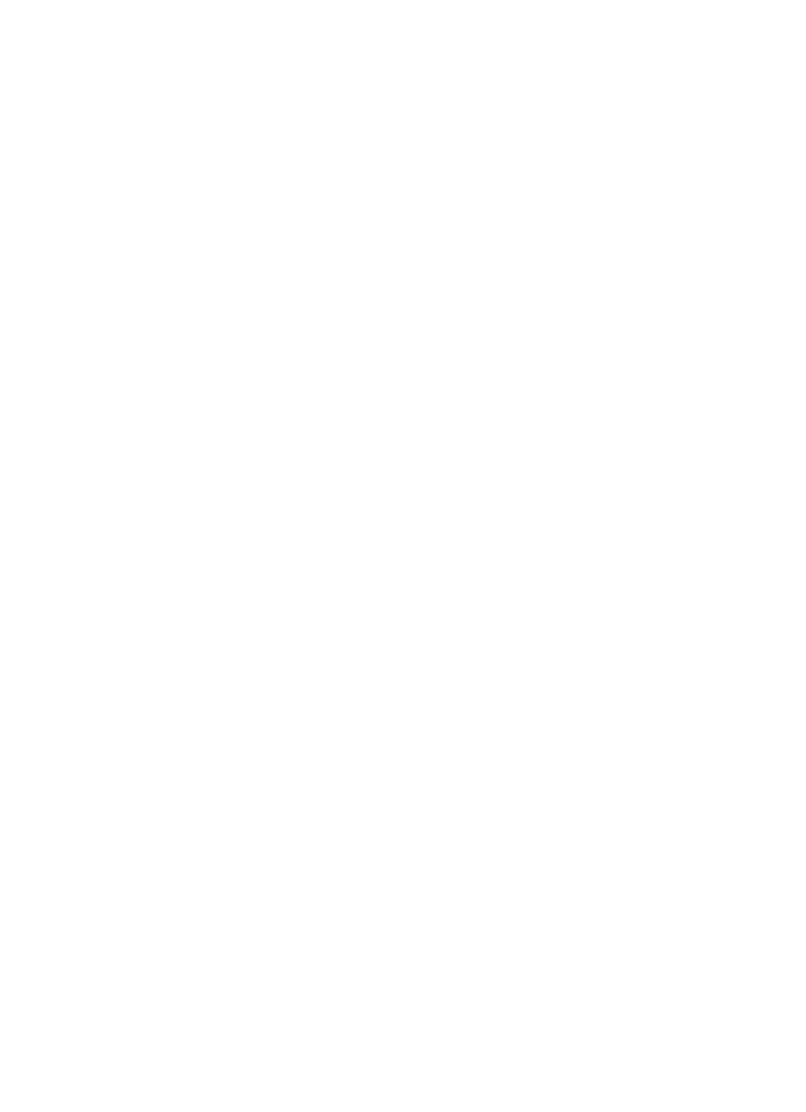

Figure 2. Existing neighbourhoods grid layout [click on figure to enlarge]

This neighbourhood, located in the north-west zone of the MMA, has a natural $15 \%$ land slope and a neighbourhood typology which responds to the low-density housing trend within the local urban expansion.

The characterization of the representative urban canyon in the selected urban scheme was carried out through a cadastral survey and aerial images obtained by using drones (Catastro, 2018). A set of urban-building indicators was determined: $150-\mathrm{m}$ block length, $16-\mathrm{m}$ street width, $200 \mathrm{~m}^{2}$ lot surface area, 0.55 floor area ratio, yard-side: $2 \mathrm{~m}$ front yard and $5.50 \mathrm{~m}$ side yard (on one of the largest sides of the plot) (Figure 3). This is in accordance to the semi-detached housing typology. The street tree alignment consists of $\mathrm{Me}$ lia azedarach (Chinaberry), a second magnitude tree
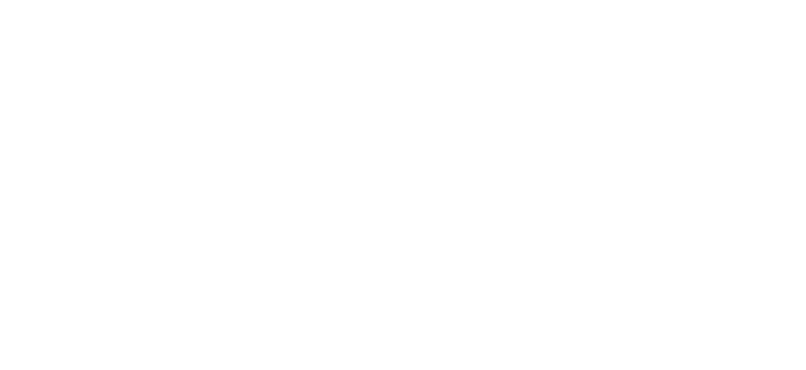

Figure 3. Current urban scheme in the piedmont area of the MMA

[click on figure to enlarge] 
species with $18 \mathrm{~m}$ maximum height, a crown diameter between 6 and $8 \mathrm{~m}$, and average solar permeability of $48 \%$ in summer (Cantón et al., 2000).

\section{Proposed urban schemes}

Based on a cadastral survey analysing both land topography and the urban growth logics of the entire MMA hillside area -3- three sectors of potential urban development were identified (North, Center, and South). These sectors present different land slopes (15, 25 , and $30 \%$ respectively) (Figure 4 ).

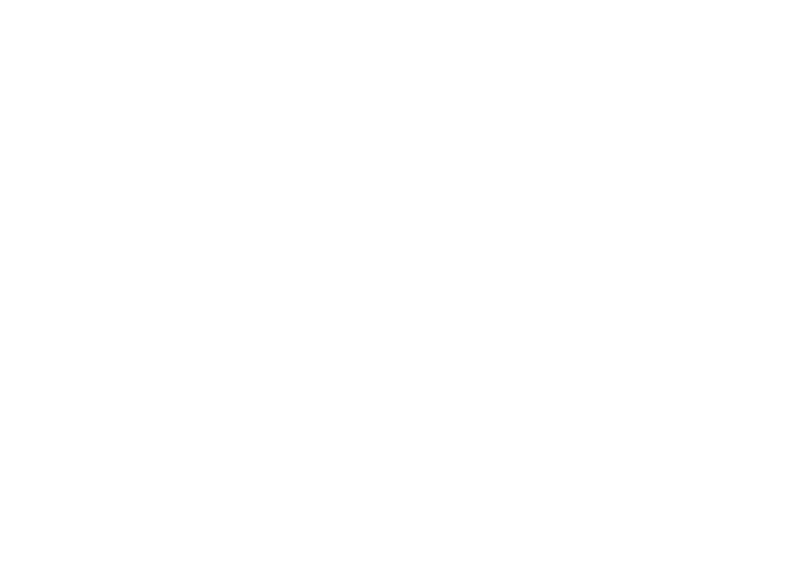

Figure 4. Identification of different suitable sectors for hillside urbanization with the incorporation of land level and urban schemes adapted to piedmont conditions [click on figure to enlarge]

The design considerations that define the proposed schemes arise from the statistical analysis of the different micro-climatic behaviours of previously monitored urbanizations (Castillo et al., 2019), and from a bibliographic review of international and local norms that regulate urban hillside development (Castillo et al., 2017). Based on this, two grid types were proposed: a) Linear organic grid with public green space with a distributed design scheme regarding vegetation typology: $10 \%$ open space with forestation in the central area, $40 \%$ sealed surface in the semi-perim-

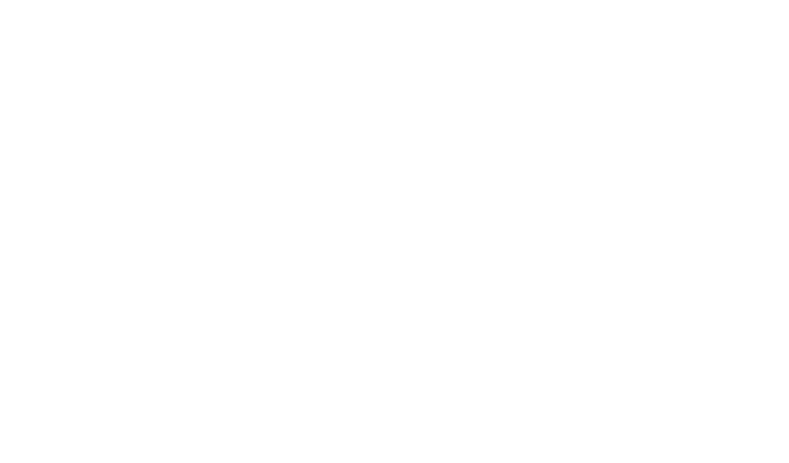

Figure 5. Proposed urban schemes adapted to hillside conditions [click on figure to enlarge] eter area, and $50 \%$ forestation in the perimeter area (Stocco, 2016); and b) Organic grid with Cul-de-Sac a dead-end, usually a looped or circular road (urban dictionary, s-d), without public green space. These schemes incorporate infiltration areas in the urban canyons and inside the lots.

The following characteristics were defined for both grids: 200 -m block length, 20-m street width, and 480$\mathrm{m}^{2}$ lot surface area. American regulations were adopted for the Floor Area Ratio (FAR) of the lots. This relates land slope to land use intensity: as the slope increases, the floor area ratio decreases. Consequently, the following ratios are proposed: $30 \%$ slope $/ 0.15 \mathrm{FAR}$, $25 \%$ slope/ 0.25 FAR, and 15\% slope/0.30 FAR. To preserve sun access, spacing between buildings is defined as follows: $2 \mathrm{~m}$ frontal; $3 \mathrm{~m}$ lateral south spacing, and $11 \mathrm{~m}$ north spacing. The proposed schemes contemplate alignment trees with Morus alba species, a second magnitude street tree with a height of $12 \mathrm{~m}, 6$ to 8 $\mathrm{m}$ diameter crown size, and 32\% low solar permeability in summer (Cantón et al., 1994). The tree type selection aims to increase solar control in a high solar radiation area. Figure 5 shows the grids of the proposed urban schemes.

\section{Urban Scheme Evaluation Method}

To verify and validate the behaviour of the urban proposals, an existing representative neighbourhood of the urban piedmont area was selected and monitored. The proposed schemes were micro-climatically simulated using the ENVI-met software. The results of these simulations were adjusted to those obtained by monitoring the existing case.

\section{Simulation Model}

The ENVI-met 3.1 software, which is based on the fundamental laws of fluid dynamics and thermodynamics (Bruse, 1999), was used for the microclimatic evaluation of urban schemes. Developed by Dr. Michael Bruse's Environmental Modelling Group at the Institute of Geography of the University of Mainz, Germany (http://www.envi-met.com), this 3D computer model works on an urban scale within a daily cycle and it is designed to simulate the interactions between the air and surface of the urban environment with a typical resolution of 0.5 to 10 meters every 10 seconds. The model includes the simulation of flows around and between buildings; the heat and vapor exchange processes of soil and wall surfaces; turbulence; vegetation parameters; bioclimatology; and contaminant dispersion (Bruse, 2009). The use of ENVI-met is widely validated both locally (Alchapar, 2014; 2016; Stocco, 2016; Sosa, 2017) and internationally (Tumini \& Higueras, 2012; Tumini \& Pérez Fargallo, 2015; Perini \& Magliocco, 2014; Middel, et al., 2014; Yucekaya \& Uslu, 2020). 
For the configuration of ENVI-met theoretical models, data are incorporated in the following main input files:

- Area Input File: Created through a graphic interface, it contains data of the model's physical design values including the geographic location of the urban scheme, the building's shape and size, the vegetation, and the real soil type conditions of the monitored case study as well as the receptors located in the proposed scheme.

- Database: Data and characteristics of forestation and soil composition are incorporated in this section. The "Tb" tree species was selected from the ENVI-met PLANTS.DAT database. The height was set at $10 \mathrm{~m}$ corresponding to the average development of a second magnitude tree. This tree typology is characterized by 400 minimum stomatal resistance, 0.20 plant leaf shortwave albedo, $2 \mathrm{~m}$ root zone total depth, 0.80 to $2.00 \mathrm{~m}^{2} / \mathrm{m}^{3} \mathrm{LAD}$, and 0.10 $\mathrm{m}^{2} / \mathrm{m}^{3} \mathrm{RAD}$.

- Configuration File: This includes the meteorological data that initiates the model. The ENVI-met input variables are:10-m $(\mathrm{m} / \mathrm{s})$ wind speed, wind direction, roughness (Zo), starting atmospheric temperature, specific humidity at $2500 \mathrm{~m}$ (g water/ $\mathrm{kg}$ air), relative humidity at $2 \mathrm{~m}(\%)$, internal temperature, temperature, and soil humidity. Indoor temperature was set at $296 \mathrm{~K}\left(24^{\circ} \mathrm{C}\right)$ in accordance to the average summer indoor temperature suggested by the Argentinean Energy Department.

The initial simulation parameters must be carefully defined since predictions from the microclimatic simulations strongly depend on the initial boundary conditions and input data. Table 1 shows the input data "Configuration File" for the adjustment of the rational grid layout. This table is divided into three data categories: meteorological, building, and soil. The input meteorological data and the weather conditions at the mesoscale level are kept constant in the settings. The building data are also kept constant since both the construction technology and the materials of the existing dwellings in the case studies are the same (existing urban scheme and selected urban canyons). Finally, soil category data vary in terms of the surface temperature values of their initial and middle layers $(0$ to $50 \mathrm{~cm}$ ).

\section{Description of the simulation's physical model}

The simulations were carried out with a reference surface area of $300 \times 300 \mathrm{~m}$. The grid is $100 \times 100 \times 30$; therefore, the resolution of the area is $3 \times 3 \times 3 \mathrm{~m}$ and the total number of grids is $\mathrm{x}: 86 ; \mathrm{y}: 86 ; \mathrm{z}: 30$. To obtain data from each analysed set on the effect of the grid layout on the air temperature, nine receptors were lo-

Table 1. ENVI-met simulation input parameters

\begin{tabular}{|c|c|}
\hline Parameters for Envi-met configuration & Values \\
\hline \multicolumn{2}{|l|}{ Meteorological } \\
\hline Wind speed $10 \mathrm{~m}$ from the ground (m/s, Airport weather station observatory data) & 3.5 \\
\hline Wind direction $\left(0^{\circ}: \mathrm{N}, 90^{\circ}: \mathrm{E}, 180^{\circ}: \mathrm{S}, 270^{\circ}: \mathrm{W}\right.$ ) (Airport weather station observatory data) & 1350 \\
\hline Roughness z0 & 0.1 \\
\hline Solar adjustment factor & 1.5 \\
\hline Initial atmospheric temperature (K) (University of Wyoming, station 87418 Mendoza) & 298 \\
\hline Specific humidity at 2500 m.a.s.l. $\left(\mathrm{g} / \mathrm{kg}^{-1}\right)$ & 2.8 \\
\hline Relative humidity at $2 \mathrm{~m}$ (\%) (obtained by a measuring campaign) & 37 \\
\hline \multicolumn{2}{|l|}{ Building } \\
\hline Indoor temperature $(\mathrm{K})$ & 296 \\
\hline Wall conductivity $\left(\mathrm{W} / \mathrm{m}^{2} \mathrm{~K}\right)$ & 2 \\
\hline Roof conductivity $\left(\mathrm{W} / \mathrm{m}^{2} \mathrm{~K}\right)$ & 0.78 \\
\hline Wall albedo & 0.3 \\
\hline Roof albedo & 0.2 \\
\hline \multicolumn{2}{|l|}{ Soil } \\
\hline Initial upper soil layer temperature (K) & 293 \\
\hline Middle upper soil layer temperature (K) & 290 \\
\hline Deeper upper soil layer temperature (K) & 290 \\
\hline Initial soil layer $(0-20 \mathrm{~cm})$ moisture content $(\%)^{*}$ & 20 \\
\hline Middle soil layer $(20-50 \mathrm{~cm})$ moisture content $(\%)^{*}$ & 35 \\
\hline Deeper soil layer moisture content below $50 \mathrm{~cm}$ ) moisture content (\%)* & 60 \\
\hline
\end{tabular}

* Default ENVI-met values 


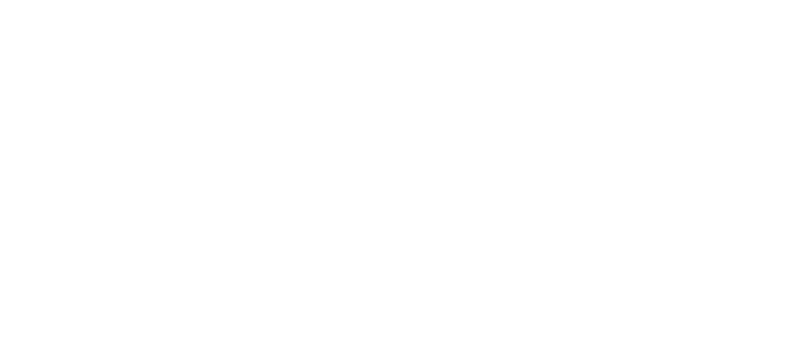

Figure 6. Location of receptors in the proposed urban grids [click on figure to enlarge]

cated in the urban canyons and six more near public green spaces, as defined in the model. The first three were placed within a $50 \mathrm{~m}$ radius and the next three within a $100 \mathrm{~m}$ radius. For the organic grid with $\mathrm{Cul}-$ de-Sac, five receptors were located in the center of each Cul-de-Sac in addition to the receptors in the urban canyons. Figure 6 shows the location of the receptors in the proposed urban grid.

\section{Adjustment of thermal behaviour results between the simulated and measured model}

To validate and give statistical reliability to the analysed urban scheme results, the urban canyon which was monitored in situ was adjusted with the numerical model. For this, microclimatic data was captured during a measuring campaign. A fixed sensor- $\mathrm{HOBO}$ UX100-003 Temperature/Relative Humidity data logger (within 3.5\% accuracy)- was installed in a solar radiation shield $2 \mathrm{~m}$ from the ground to prevent irradiation and ensure adequate air circulation (Oke, 2004). The location of the sensor in the grid is identified in Figure 6 in red. The sensor recorded data every 15 minutes during a 20-day period along the summer of 2017. January $12^{\text {th }}$ was selected as the study day since

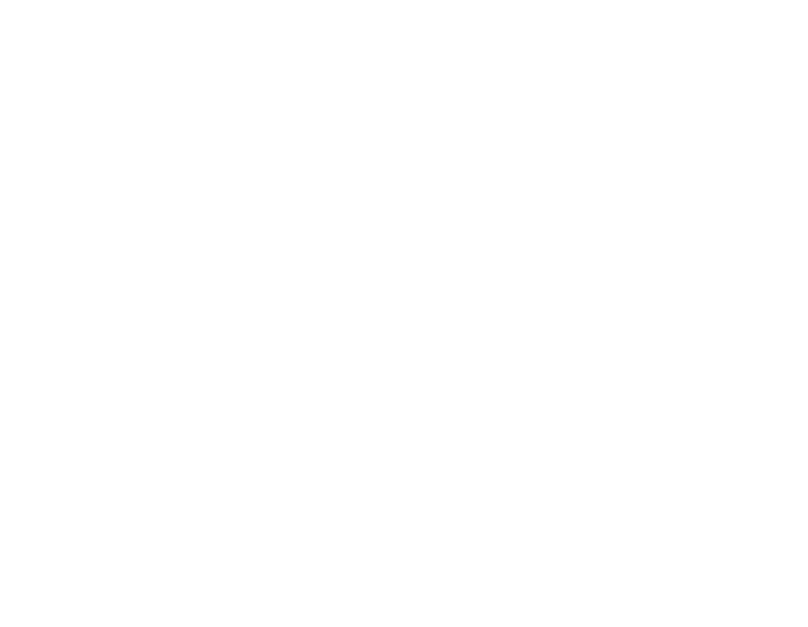

Figure 7. Photographs of the equipment used in measurement campaigns and the position of the sensors in the monitored urban canyons [click on figure to enlarge] its meteorological conditions correspond to a typical summer day in an arid region -high temperature $\left(\mathrm{T}^{\circ}\right.$ max.: $38^{\circ} \mathrm{C}, \mathrm{T}^{\circ} \min .24^{\circ} \mathrm{C}$ y amplitude: $14^{\circ} \mathrm{C}$ ), clear sky conditions, moderate wind, low relative humidity, and no precipitation - (Weather Underground). In addition, the Sky View Factor (SVF) of the monitored urban canyons was obtained by digitally processing fish-eye pictures using "Pixel de Cielo" software (Correa et al., 2006). The measured and simulated SVF value was adjusted to the corresponding receptor in the simulated grid. Figure 7 shows the equipment used to develop the monitoring campaigns.

In keeping with the results obtained by Wang \& Akbari (2016), the stabilization period for the simulation process was 72 hours. Moreover, as stated in their findings, only the values for the last 24 hours were considered valid output to correctly reproduce the phenomenology of the selected day.

Figure 8 and Table 2 show the adjustment values used to validate the reliability of the simulation results. The error rate resulting from their use was evaluated based on the comparative analysis of the simulated and measured air temperature curve (Figure 8). Error identification and quantification was performed by determining: the adjusted correlation coefficient of determination (R2), the mean bias error (MBE), the mean absolute error (MAE), the mean absolute percent error (MAPE), the root mean square error (RSME), the systematic root mean square error (RSMEs) and the random mean square error (RSMEu). Each indicator expresses the model's accuracy or error rate from different perspectives. While MAPE expresses the error as a percentage, the MAE and RMSE indicate the magnitude of the average error. The MBE, on the other hand, describes error bias direction whose value is related to the magnitude of the used values; a negative MBE occurs when predicted values are smaller than the observations. The statistical analysis that characterizes and compares the data shows a good prediction of the thermal behaviour of the evaluated day, with an R2 $=0.93$ coefficient of determination and an RMSE $=2.2$ mean square root error. Table 2 shows the adjustment data of the simulated case with the maximum, minimum, average, and amplitude air temperature values, as well as SVF values and the six statistical indicators used to estimate the accuracy of the numerical model versus the real one (Alchapar and Correa, 2016; Sosa et al., 2018). There are also acceptable low magnitudes of RMSE and their components-RMSES and RMSEU-suggesting that these base scenarios are largely accurate. MBE is equal to $-1.9^{\circ} \mathrm{C}$, indicating an underestimation of the average amount.

In Figure 8, results show a similar correspondence between the fixed point and the simulated point, the R2 indicates a good accuracy of the model (0.93). 
Table 2. Statistical indicators. January $12^{\text {th }}$

\begin{tabular}{|l|c|c|c|c|c|}
\hline $\mathrm{T}^{\circ}$ & Max. & Min. & Av. & Amp. & SVF \\
\hline Simulated & 34.56 & 22.72 & 27.52 & 11.84 & 0.69 \\
\hline Measured & 34.96 & 22.48 & 28.86 & 12.48 & 0.62 \\
\hline Delta & 0.40 & -0.24 & -1.34 & 0.64 & 0.07 \\
\hline
\end{tabular}

\begin{tabular}{|c|c|c|c|c|c|}
\hline MBE & MAE & MAPE & RMSE & RMSEs & RMSEu \\
\hline-1.9 & 0.5 & $-6.1 \%$ & 2.2 & 1.0 & 1.1 \\
\hline
\end{tabular}
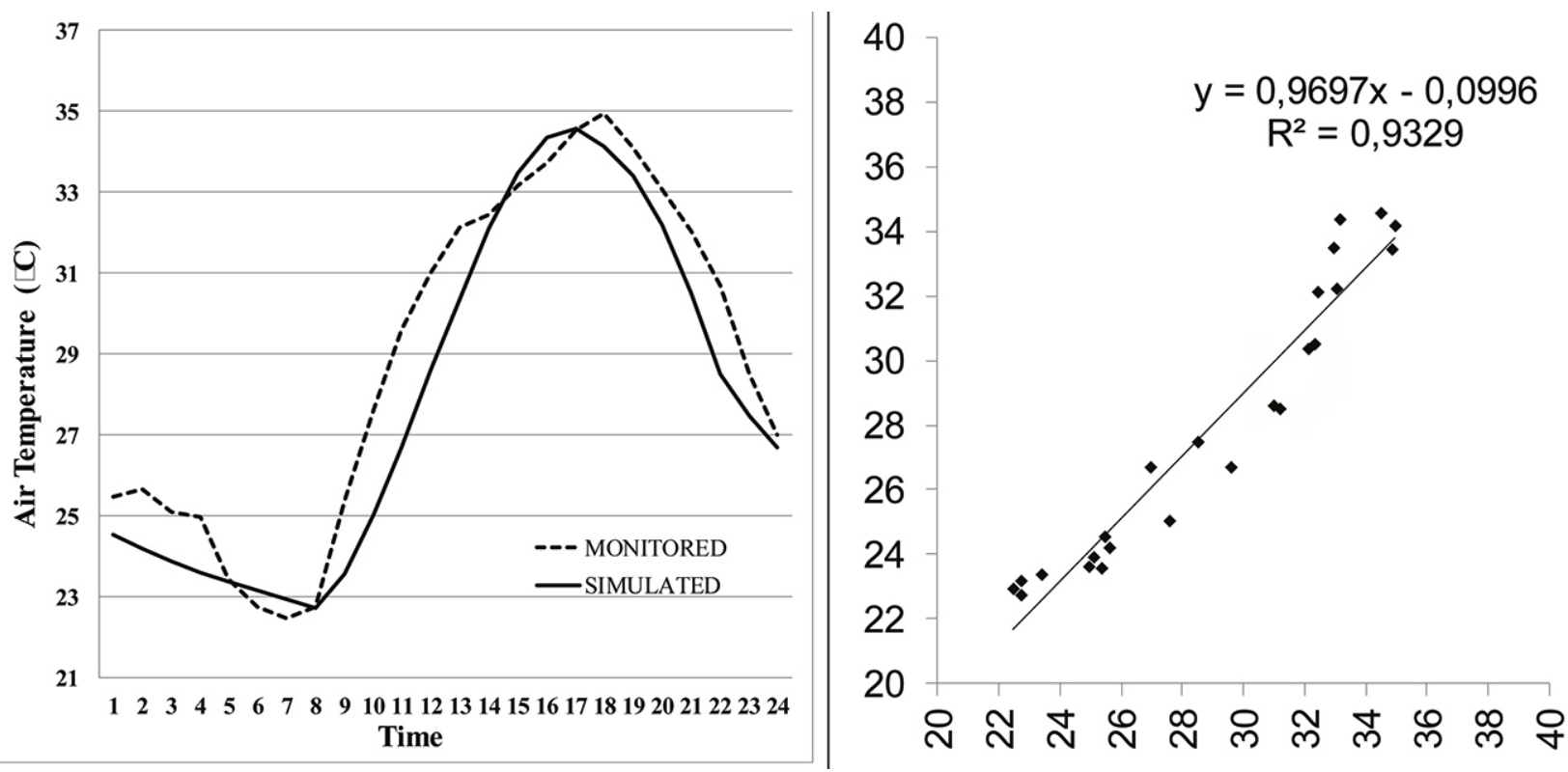

Figure 8. Adjustment curve of the simulated case

\section{Results}

In order to identify the urban scheme with the best thermal response, a comparative analysis of maximum- minimum and average air temperatures reached on a typical summer day was carried out together with a box-plot analysis showing the variability of the thermal responses of each scheme.

\section{Comparative analysis of average maximum,} minimum, and mean air temperatures

The results of the ENVI-met simulations are shown below. Table 3 shows the results of the average temperatures of all the receptors corresponding to the maximum, minimum, and average air temperature curve. These were calculated from the results of the receptors placed in the seven simulated schemes -the existing case and six urban schemes adapted to the different slope degrees. These results correspond to the behaviour of the three evaluated schemes -the existing scheme and two proposed urban schemes- in the three analysed slopes -30, 25, and 15\%-.
Based on the average thermal responses of the analysed urban schemes, Table 3 reveals that the linear organic grid with distributed public green space has the best thermal performance on all slopes. This scheme design is also beneficial considering its simplicity and economy in terms of infrastructure and street layout when compared to the organic grid with Cul-de-Sac. This allows its replication in different hillside areas.

Regarding maximum and average temperatures, improvements are more noticeable as the slope decreases with differences from around $1.6^{\circ} \mathrm{C}$ to $2^{\circ} \mathrm{C}$. The organic grid with Cul-de-Sac is the least favourable alternative since it reaches higher minimum temperature values than the existing scheme and the difference between maximum and average temperature values is minimum compared with the existing case. Finally, the proposed schemes show a low impact over minimum temperature. 
Table 3. Average temperatures of the analysed schemes

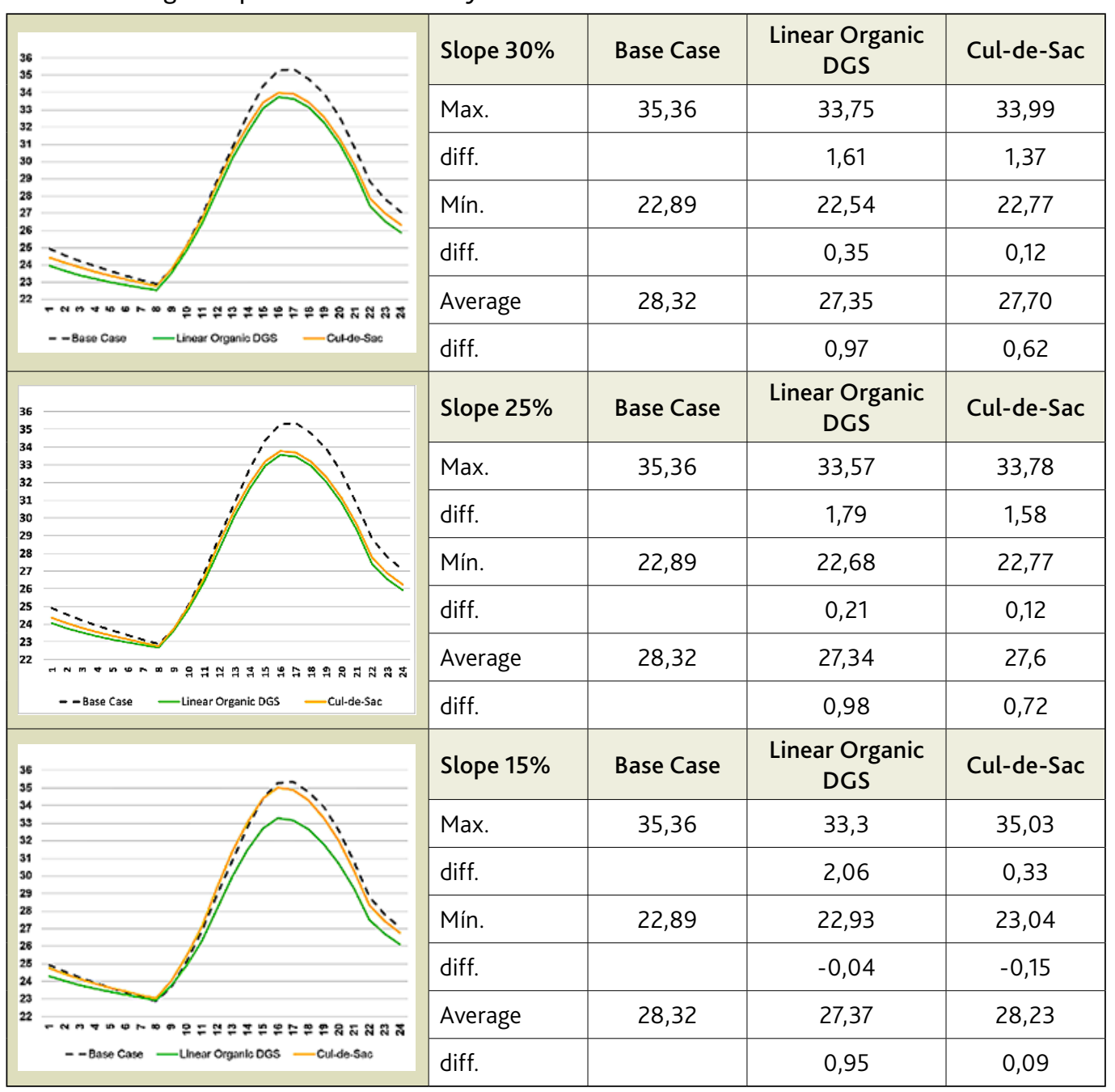

\section{Temperature distribution analysis}

Box-plot graphs were produced to contrast the behaviour of all the receptors located in the different points of the urban schemes. These graphs show the maximum, minimum, and average temperature distribution.

\section{Maximum temperature}

Figure 9 shows the variability of the maximum temperatures of all the receptors located in the seven urban schemes. When comparing the values of each slope, the schemes located on the $15 \%$ slope are those that reach the lowest maximum temperature values. In addition, the organic linear grid with green space distributed over the $15 \%$ slope has the best behaviour with a greater differentiation from the base case and the lowest variability of maximum temperatures, with $75 \%$ of the values between $33.45^{\circ} \mathrm{C}$ and $34.23^{\circ} \mathrm{C}$ (quartiles Q1 and Q3). This responds to two components present in this scheme, namely, the increase in thermal inertia caused by an increase in land use in- tensity. It should be noted that regulations for hillside urbanization for soils with a $15 \%$ slope establish an $0.30 \mathrm{FAR}$ and the existence of green space. A marked decrease in maximum temperatures becomes evident when comparing the values of the proposed schemes with those of the existing scheme. The latter displays a value of $36^{\circ} \mathrm{C}$ in the $\mathrm{Q} 1$ quartile against the most efficient proposed urban scheme with a value of $33.5^{\circ} \mathrm{C}$.

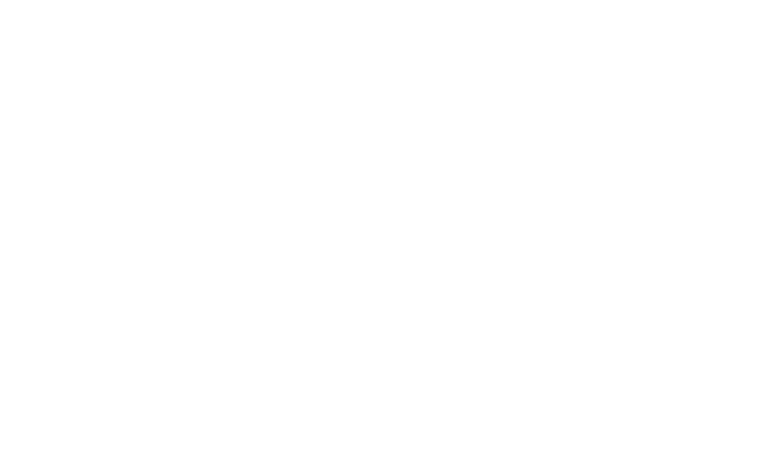

Figure 9. Box-plot graph for maximum temperatures of the seven proposed schemes [click on figure to enlarge] 


\section{Minimum temperature}

The minimum temperature variability diagram (Figure 10) shows that linear organic grids with distributed green space have the greatest value variability, but also the lowest minimum temperature, reaching Q1= $22.5{ }^{\circ} \mathrm{C}$ at the $30 \%$ slope. This is because their morphology with vegetated areas affects temperature decrease at night.

Unlike the maximum temperatures, schemes located on a $15 \%$ slope have the highest minimum temperature values and the lowest variability. Hence, it can be inferred that there is a more exposed surface allowing an increased night cooling in scenarios with steeper slopes.

\section{Average Temperature}

Figure 11 shows the box-plot graph with the distribution of values in the different schemes for the average temperature variable. It highlights the lowest variability in the linear organic grid with distributed green space located at the $15 \%$ slope, with values between $27.5^{\circ} \mathrm{C}$ and $27.9^{\circ} \mathrm{C}$. In addition, this scheme reaches the lowest temperatures $\left(27^{\circ} \mathrm{C}\right)$ on the $30 \%$ slope. The linear organic grid with distributed green space located in slopes of $30 \%$ and the Cul-de-Sac grid in all slopes show the highest average temperature variability.

\section{Evaluation of thermographic images of the existing urban scheme according to the urban proposal schemes}

This section presents thermographic images obtained from the simulation results with the application of Leonardo v3.7, an extension of ENVI-met software (Figure 12). They correspond to maximum air temperature distribution at $2 \mathrm{~m}$ height for each scheme for January 12, 2017, at 16:00 h.

When analysing the maximum temperature images of the proposed scenarios, the images show that:

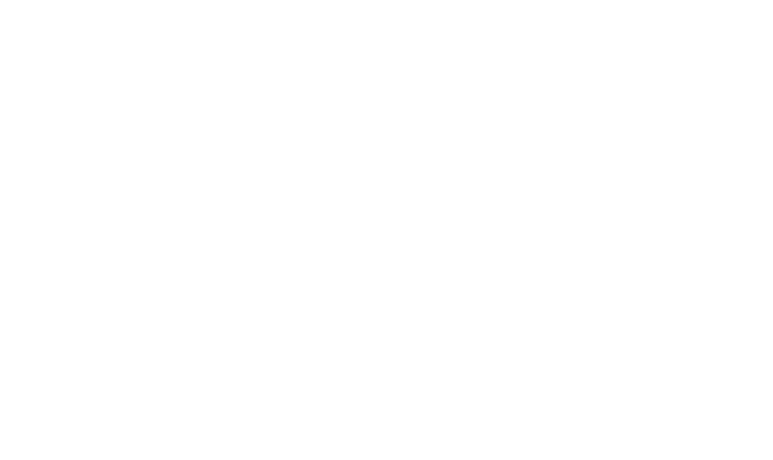

Figure 10. Box-plot graph for minimum temperatures of the seven proposed schemes [click on figure to enlarge]

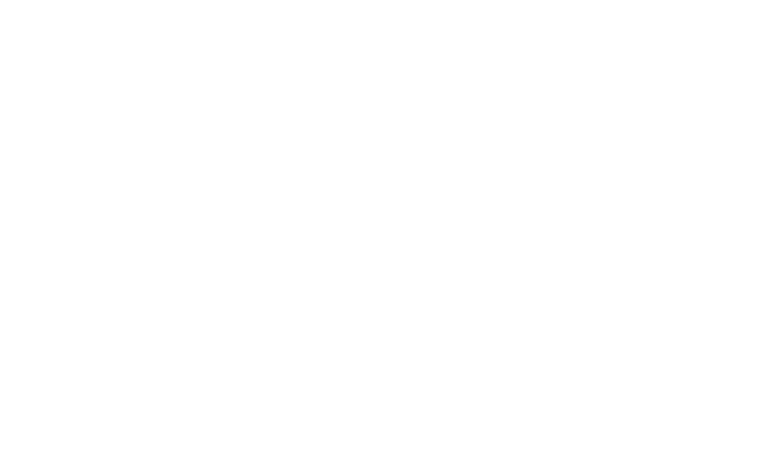

Figure 11. Box-plot graph for average temperatures of the seven proposed schemes [click on figure to enlarge]

- The base case -rational grid used on the flatlandconcentrates the largest areas and hot spots, both in the streets and courtyards of the blocks located in the S-E edge of the analysed area.

- Temperature values decrease as the slope decreases.

- Schemes adapted to hillside conditions show a homogeneous distribution of cool areas, since the backyards present similar temperature behaviour as the road channels.

- Public green spaces incorporated in the organic linear grid schemes provide a slight microclimatic influence to its environment. 


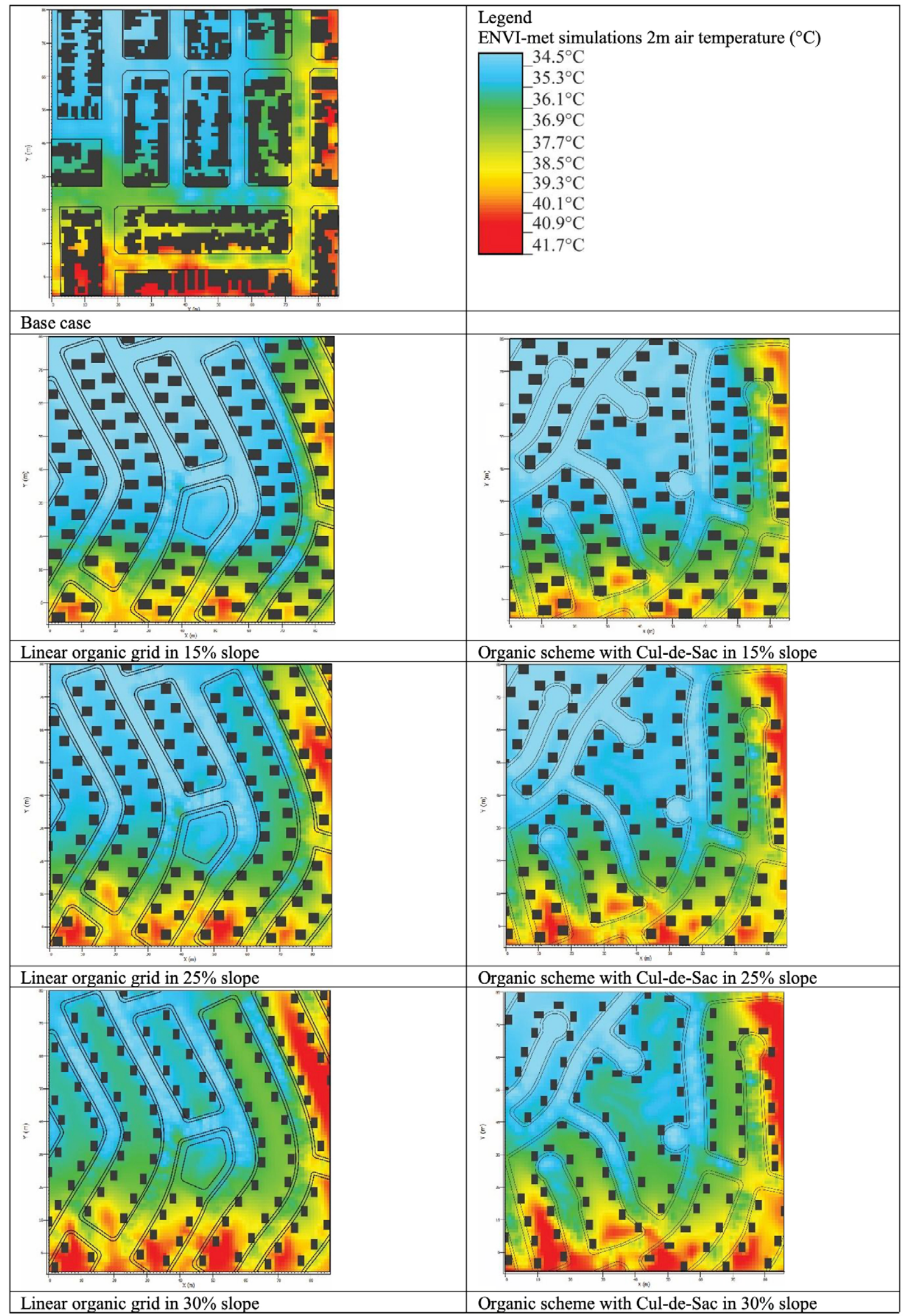

Figure 12. Thermographic images of maximum temperature for January $12,2017,16: 00 \mathrm{~h}$ 


\section{Discussion}

The results within the present study show that organic linear plot schemes with higher soil occupation achieve a decrease in air temperature of $2{ }^{\circ} \mathrm{C}$ in relation to the base case during the day. When comparing the morphology of both schemes, it is observed that the base case presents a compact pattern that, for hillside conditions, is the most beneficial typology. (Castillo et al., 2018). These results are consistent with those achieved by Middel et al. (2014) which point out that regarding urban form, compact scenarios present the most advantages for daytime temperature cooling, reaching differences of $2{ }^{\circ} \mathrm{C}$ with respect to spread schemes in flatland areas. However, compact grids do not allow adaptation to terrain with marked unevenness and generate high soil sealing. This implies the removal of natural terrain and the reduction of infiltration and runoff in an area with high alluvial risk. Responding to these conditions requires the use of a spread type organic grid and the control of the solar resource from the use of forestall species. Unlike state of art parameters related to the greater thermal efficiency of compact forms, this work has shown that it is possible to simultaneously improve the thermal behaviour of the urban area and respond to the environmental limitations of the hillside. This is achieved through open, strongly shaded organic type urban proposals, with a predominantly North-South orientation to accompany the levels of the natural terrain and the incorporation of open vegetated spaces of a public nature. These schemes allow an air temperature decrease of $2{ }^{\circ} \mathrm{C}$, a magnitude comparable to those achieved in compact-type grids.

Concerning the impact of shaded areas on the microclimatic response of the plot, the results are similar to those discussed by Middel et al. (2015). These authors demonstrated that an increase of the current shaded area from $10 \%$ to $25 \%$ in the City of Phoenix an arid zone city similar to the case study- would allow a reduction in daytime temperature by $2{ }^{\circ} \mathrm{C}$ on a neighbourhood scale. At the local level, Alchapar et al. (2016) analysed the impact of different urban cooling strategies applied in open type rational grids inserted in flatlands areas. The results also show that vegetation increase improves urban thermal conditions, reducing maximum air temperatures by $1.7^{\circ} \mathrm{C}$. Finally, Maleki and Mahdavi (2016) establish that the increase in vegetation combined with the incorporation of permeable pavements would reduce air temperature. This combination of strategies is aligned with the proposals of this work which dispose areas of permeable land to improve infiltration, slow down the speed of runoff and reduce the risk of avalanches.

Regarding the orientation of the urban grid, AliToudert and Mayer (2006) point out that in arid areas, the rotation of the streets towards a predominantly North-South orientation leads to better comfort conditions due to a greater efficiency of the shading effect of vertical envelopes with respect to East-West orientations. In their studies for Mendoza's City, Sosa et al. (2018) found that North-South grid orientations show the highest energy efficiency during the summer period. The results discussed are analogous to those achieved in this work.

In addition, it has been shown that the efficiency of the incorporation of vegetation is associated with its location in the context of urbanization type and green distribution. In this sense, Middel et al. (2015) have determined that the strategy of locating green space affects pedestrian comfort and improves energy savings in buildings. Declet-Barreto et al. (2013) indicate that temperature reductions are associated with the type of vegetation, reaching a $2{ }^{\circ} \mathrm{C}$ temperature decrease in vegetated areas with grass and up to $8{ }^{\circ} \mathrm{C}$ in wooded areas. At local level, Stocco et al. (2020) determined the proportion and distribution of vegetation in open public spaces that contributes to achieving the best thermal conditions and urban comfort. The results show that the most effective scheme for the rehabilitation of squares is the one that concentrates $60 \%$ of the wooded land around a sealed center with an area that does not exceed $20 \%$ of the square's surface. In this work, the vegetated public space is centrally located on the urbanization proposal and its design responds to the previously described criteria.

Finally, the methods used in the compilation of the state of art developed by Santamouris et al. (2017) and Tsoka et al. (2018), as well as those used in the previously cited works, validate the methodological design and tools used in this research. In addition, it shows that they are relevant for the prediction and analysis of the thermal behaviour associated with the development of urban proposals. 


\section{Conclusions}

Considering the comparative analysis of the proposed schemes regarding the prevailing urbanization pattern of hillside areas, this work concludes that it is possible to improve the microclimate of the urban frame and to respond to the intrinsic characteristics of the piedmont. Moreover, linear organic grids with North-South orientation, which are strongly shaded and have public green spaces, decrease air temperature by up to $2^{\circ} \mathrm{C}$.

Regarding the proposed schemes, results show that the highest energy efficiency in hillside areas happens with slighter slopes. This is due to higher land occupation patterns associated with the increase of the FAR index. This condition rises the thermal grid inertia provoking an impact on the attenuation of maximum temperatures. Considering that $70 \%$ of the developable land corresponds to slope values lower than or equal to $15 \%$, an improvement in micro-climatic performance would be achieved by the adoption of design criteria incorporated in the linear organic grid with distributed green space in future hillside urban developments. In lands with the greatest slopes, urbanization patterns are hotter during the day (around $0.5^{\circ} \mathrm{C}$ ) and slightly cooler at night. In addition, proposals incorporating vegetation as a solar control strategy and a greater proportion of permeable surface allow water infiltration from summer storms. This links the geomorphologic limitations of the insertion context with its micro- climate. Another favourable aspect within this proposal is the simplicity of its design since it is better in terms of accessibility and service distribution due to its linear urban morphology when comparing the organic grid with Cul-de-Sac.

From the methodological point of view, the present study demonstrates the potential of ENVI-met software as a prediction tool since it reliably reproduces the main processes of atmospheric change that affect the microclimate of a sector: wind flows, radiation, temperature, and humidity. This tool simplifies and facilitates the work of urban planners and architects as it determines the urban-build design variables with the greatest impact on the thermal behaviour of development areas. Therefore, it can be inferred that the use of micro-climatic simulation is fundamental in the process of urban-build design. In addition, simulation allows measurement testing and a better understanding of how each urbanization scheme component works. This makes it possible to analyse the performance of theoretical proposals that cannot be evaluated by on-site measurements.

Finally, this work presents the likelihood of urbanization in areas of high fragility by developing design proposals which consider the potentialities and limitations of the insertion context by means of controlling the environmental impact of urbanization and planning urban growth within the framework of sustainable development testing.

\section{References}

Abraham, E., Roig, F., \& Salomón, M. (2005). Planificación y gestión del piedemonte al oeste de la Ciudad de Mendoza. Un asunto pendiente [Planning and management of the hillside west of the city of Mendoza. An unfinished business]. IADIZA, CONICET. Argentina. (in Spanish).

Akbari, H., Menon, S., \& Rosenfeld, A. (2009) Global cooling: increasing world-wide urban albedos to offset $\mathrm{CO}_{2}$. Climatic Change, 94, 275 - 286. https:// doi.org/10.1007/s10584-008-9515-9.

Alchapar, N., \& Correa, E. (2015). Comparison of the performance of different facade materials for reducing building cooling needs. Eco-Efficient Materials for Mitigating Building Cooling Needs Design, Properties and Applications. 155-194. https://doi. org/10.1016/B978-1-78242-380-5.00006-6

Alchapar, N., \& Correa, E. (2016). Pautas de diseño para disminuir las temperaturas urbanas en regiones con alta productividad solar. Parámetros morfológicos y materiales. [Design guidelines to reduce urban temperatures in regions with high solar productivity. Morphological and material parameters]. Hábitat Sustentable, 6(1), 84-95. http://revistas.ubiobio.cl/index.php/RHS/article/view/2366 (in Spanish with English summary).

Alchapar, N. (2014). Materiales de la envolvente urbana. Valoración de su aptitud para mitigar la isla de calor en ciudades de zonas áridas [Materials of the urban envelope Assessment of its aptitude to mitigate the heat island in cities of arid zones]. Argentina: National University of Salta, Salta. (in Spanish with English summary).

Alchapar, N., Pezzuto, C., Correa, E., \& Labaki, L. (2016). The impact of different cooling strategies on urban air temperatures: the cases of Campinas, Brazil and Mendoza, Argentina. Theoretical and Applied Climatology, 130, 35-50. https://doi. org/10.1007/s00704-016-1851-5 
Ali-Toudert, F., \& Mayer, H. (2006). Numerical study on the effects of aspect ratio and orientation of an urban street canyon on outdoor thermal comfort in hot and dry climate. Building and Environment, 41(2), 94-108. https://doi.org/10.1016/j.buildenv.2005.01.013

Allegrini, J., Dorer, V., \& Carmeliet, J. (2015). Influence of morphologies on the microclimate in urban neighbourhoods. Journal of Wind Engineering and Industrial Aerodynamics, 144, 108-117. https:// doi.org/10.1016/i.jweia.2015.03.024

Boutet, M.L., Hernández A.L., \& Jacobo, G.J. (2016). Thermo - lighting optimization proposal for school buildings in subtropical hot - humid climates: Monitoring and computer simulation on autumn period. Energy and Buildings, 128, 785-797. https:// doi.org/10.1016/j.enbuild.2016.07.028

Bruse, M., \& Fleer, H. (1998a). Simulating surfaceplant-air interactions inside urban environments with a three dimensional numerical model. Environmental Modelling \& Software, 13(3-4), 373-384. https://doi.org/10.1016/S1364-8152(98)00042-5

Bruse, M. (1999). The influences of local environmental design on microclimate. Bochum, Germany: University of Bochum.

Bruse, M. (2009). Stadtlandschaft im Klimawandel $\mathrm{Zu}$ den Grundlagen des städtischen Mikroklimas. [Urban Landscape in Climate Change - On the Fundamentals of the Urban Microclimate]. In: H.D. Collinet, \& F. Pesch (Eds.), Stadtund Landschaft. Essen: Klartext Verlag. (in German with English summary).

Cantón, M.A., Cortegoso, J.L., \& De Rosa, C. (2000). Environmental and energy impact of the urban forest in arid zone cities. Architectural Science Review, 44(1), 3-16. https://doi.org/10.1080/00038628.2001. 9697448

Cantón, M.A., Cortegoso, J.L., \& de Rosa, C. (1994). Solar permeability of urban trees in cities of western Argentina. Energy and Buildings, 20(3), 219230. https://doi.org/10.1016/0378-7788(94)90025-6

Castells, D. (2017). The challenges of a Crowded Planet. The observer. RBA Editors.

Castillo, A.L., Correa, E.N., \& Cantón, M.A. (2019). Geomorfología y forma urbana. Comportamiento térmico de distintas tramas en áreas de piedemonte: el caso de Mendoza, Argentina. [Geomorphology and urban form. Thermal behavior of different frames in hillside areas: the case of Mendoza, Argentina]. EURE Magazine - Journal of Urban Regional Studies, 45, 136. http://dx.doi.org/10.4067/ S0250-71612019000300183. (in Spanish with English summary).

Castillo, A.L., Correa, E.N., \& Cantón, M.A. (2017). Regulación urbanística de áreas de piedemonte en ciudades latinoamericanas. Análisis crítico de la normativa internacional y el marco regulatorio de la ciudad de Mendoza. [Urban regulation of hillside in Latin American cities. Critical analysis of international regulations and the regulatory framework of the City of Mendoza, Argentina]. ACE: Architecture, City and Environment, 12, 39-70. https://doi. org 10.5821/ace.12.35.476. (in Spanish with English summary).

Castillo, A. L., Sosa, M. B., Correa, E. N., \& Cantón, M. A. (2018). Comportamiento y confort térmico exterior de canales viales urbanos insertos en diversas tramas y geomorfologías de Mendoza. [The behavior and outdoor thermal comfort of urban canyons in different weft and geomorphologies of Mendoza, Argentina]. Revista hábitat sustentable, 8(2), 116129. https://doi.org/10.22320/07190700.2018.08.02. $\underline{09}$ (in Spanish with English summary).

Correa E.N., Ruiz, M.A., Canton, M., \& Lesino, G. (2012). Thermal comfort in forested urban canyons of low building density. An assessment for the city of Mendoza, Argentina. Building and Environment, 58, 219-230. https://doi.org/10.1016/j.buildenv.2012.06.007

Correa, E.N. (2006). Isla de Calor Urbana. El caso del Área Metropolitana de Mendoza. [Urban Heat Island. The case of the metropolitan area of Mendoza]. Salta: National University of Salta. (in Spanish with English summary).

Correa, E.N., De Rosa, C., \& Lesino, G. (2006). Isla de calor urbana. Distribución espacio-temporal de temperaturas dentro del Área Metropolitana de Mendoza. [Urban heat island. Spatial-temporal distribution of temperatures within the metropolitan area of Mendoza]. Avances en Energías Renovables $y$ Medio Ambiente (AVERMA), 10, 121-128. http:// sedici.unlp.edu.ar/handle/10915/88447 (in Spanish with English summary).

Crank, P. J., Sailor, D. J., Ban-Weiss, G., \& Taleghani, M. (2018). Evaluating the ENVI-met microscale model for suitability in analysis of targeted urban heat mitigation strategies. Urban Climate, 26, 188197. https://doi.org/10.1016/j.uclim.2018.09.002

Da Cunha, J. M. P., \& Vignoli, J. R. (2009). Crecimiento urbano y movilidad en América Latina. [Urban growth and mobility in Latin America]. Revista Latinoamericana de Población, 3(4), 27-64. http:// dx.doi.org/10.31406/relap2009.v3.i1.n4-5.1 (in Spanish with English summary).

Declet-Barreto, J., Brazel, A. J., Martin, C. A., Chow, W. T., \& Harlan, S. L. (2013). Creating the park cool island in an inner-city neighborhood: heat mitigation strategy for Phoenix, AZ. Urban Ecosystems, 16(3), 617-635. https://doi.org/10.1007/s11252012-0278-8 
Doulos, L., Santamouris, M., \& Livada, I. (2004). Passive cooling of outdoor urban spaces. The role of materials. Solar energy, 77(2), 231-249. https://doi. org/10.1016/j.solener.2004.04.005

Dirección General de Catastro Mendoza. [General Directorate of Cadastre]. (2018). Mendoza Government. Argentina.

Gill, S. E., Handley, J. F., Ennos, A. R., \& Pauleit, S. (2007). Adapting cities for climate change: the role of the green infrastructure. Built environment, 33(1), 115-133. DOI: 10.2148/benv.33.1.115

Gómez, V., Faggi, A., \& Martínez Carretero, E. (2017). Estudios preliminaries acerca del Impacto de la urbanización del Piedemonte Mendocino sobre la Avifauna silvestre. [Preliminary studies on the impact of the urbanization of the piemonte of Mendoza on the wild avifauna]. Workshop de la Red Iberoamericana de Observación Territorial. (in Spanish).

Haller, A. (2017). Los impactos del crecimiento urbano en los campesinos andinos. Un estudio de percepción en la zona rural-urbana de Huancayo, Perú. [The impacts of urban growth on Andean farmers. A perception study in the rural-urban area of Huancayo, Peru]. Espacio y Desarrollo, 29, 37-56. https://doi.org/10.18800/espacioydesarrol$\underline{10.201701 .002}$

Kottek, M., Grieser, J., Beck, C., Rudolf, B., \& Rubel, F. (2006). World map of the Köppen-Geiger climate classification updated. Meteorologische Zeitschrift 15(3), 259-263. doi:10.1127/0941-2948/2006/0130. (in English with German summary).

Kuo-Tsang, H., y Yi-Jhen, L. (2017). Impact of street canyon typology on building's peak cooling energy demand. Energy and Buildings, 154, 448-464. doi: 10.1016/j.enbuild.2017.08.054

Ramakreshnan, L., Aghamohammadi, N., Fong, C.S., Ghaffarianhoseini, A., Ghaffarianhoseini, A., Wong, L.P., Hassan, N., \& Sulaiman, N.M. (2018). A critical review of urban heat island phenomenon in the context of greater Kuala Lumpur, Malaysia. Sustainable Cities and Society, 39, 99-113, https:// doi.org/10.1016/j.scs.2018.02.005.

Mesa, A., \& Giusso, C. (2014). La urbanización del Piedemonte Andino del Área Metropolitana de Mendoza, Argentina: vulnerabilidad y segmentación social como ejes del conflict. [The urban development at the Andean piedmont in the Metropolitan area of Mendoza, Argentina. Vulnerability and social segmentation as axes of conflicto]. RIURB Revista Iberoamericana de Urbanismo, 11. http://sedici.unlp.edu.ar/handle/10915/101633 (in Spanish with English summary).

Rodríguez, M. L. (2008). Riesgo en el piedemonte del Gran Mendoza por avance urbano. Argentina. [Risk in the hillsides of Great Mendoza due to ur- ban advance. Argentina]. Tiempo y espacio, (21), 4757. (in Spanish with English summary).

Maggiotto, G., Miani. A., Rizzo, E., Castellone, M.D., \& Piscitelli P. (2021). Heat waves and adaptation strategies in a Mediterranean urban context. Environmental Research, 197, 111066. https://doi. org/10.1016/j.envres.2021.111066

Maleki, A., \& Mahdavi, A. (2016). Evaluation of urban heat islands mitigation strategies using $3 \mathrm{di}$ mentional urban micro-climate model ENVI-met. Asian Journal of Civil Engineering (BHRC), 17(3), 357-371.

Mendoza Aero Observations SAME. Francisco Gabrielli Airport (2014) Station number: 87418. http:// www.wunderground. com/history/airport/SAME/

Merlier, L., Frayssinet, L., Johannes, K., \& Kuznik, F. (2019). On the impact of local microclimate on building performance simulation. Part II: Effect of external conditions on the dynamic thermal behavior of buildings. Building Simulation, 12(5), 747757. https://doi.org/10.1007/s12273-019-0508-6.

Middel, A., Chhetri, N., \& Quay, R. (2015). Urban forestry and cool roofs: Assessment of heat mitigation strategies in Phoenix residential neighborhoods. Urban Forestry \& Urban Greening, 14(1), 178-186. https://doi.org/10.1016/j. ufug.2014.09.010

Middel, A., Häb, K., Brazel, A.J., Martin, C.A., \& Guhathakurta, S. (2014). Impact of urban form and design on midafternoon microclimate in Phoenix Local Climate Zones. Landscape and Urban Planning, 122, 16-28. https://doi. org/10.1016/j.landurbplan.2013.11.004.

Mirzaei, P., \& Haghighat, F. (2010). Approaches to study Urban Heat Island, Abilities and limitations. Building and Environment; 45-10, 2192-2201. http:// dx.doi.org/10.1016/j.buildenv.2010.04.001

Morille, B., Lauzet, N., \& Musy, M. (2015). SOLENEmicroclimate: A Tool to Evaluate Envelopes Efficiency on Energy Consumption at District Scale. Energy Procedia, 78,1165-1170, https://doi. org/10.1016/j.egypro.2015.11.088.

Moschella, P. (2017). Variación del paisaje para la gestion sostebible del territorio. [Variation of the landscape for the sustainable management of the territory]. In J. Stillemans, J. Canziani, M. Vilela \& P. Dam Mazzi (Eds.), Transversal: Integration actions in the Peruvian territory (pp. 333-346). Lima: Pontifical Catholic University of Peru.

Oke, T.R. (2004) Initial Guidance to Obtain Representative Meteorological Observations at Urban Sites IOM Report No. 81, WMO/TD No. 1250, WMO, Geneva.

Palme, M., Inostroza, L., Villacreses, G., Lobato-Cordero, A., \& Carrasco, C. (2017). From urban climate to energy consumption. Enhancing building 
performance simulation by including the urban heat island effect. Energy and Buildings, 145,107120. https://www.sciencedirect.com/science/article/abs/pii/S0378778817311027

Perini, K., \& Magliocco, A. (2014). Effects of vegetation, urban density, building height, and atmospheric conditions on local temperatures and thermal comfort. Urban Forestry \& Urban Greening, 13, 495506. http://dx.doi.org/10.1016/j.ufug.2014.03.003

Perini, K., Chokhachian, A., Dong, S., \& Auer, T. (2017). Modeling and simulating urban outdoor comfort: Coupling ENVI-Met and TRNSYS by grasshopper, Energy and Buildings,152, 373-384. https://doi.org/10.1016/j.enbuild.2017.07.061.

Ruiz, M.A., \& Correa, E.N. (2015). Influencia de esquemas urbano-forestales sobre el consuemo energético residencial en una "ciudad oasis" de zona árida. [Influence of urban-forest schemes on residential energy consumption in an "oasis city" of arid zone]. Avances en Energías Renovables y Medio Ambiente, 19, 01.23-01.34. (in Spanish with English summary).

Santamouris, M. (2016). Cooling the buildings - past, present and future. Energy and Buildings, 128, 617638. https://doi.org/10.1016/j.enbuild.2016.07.034

Santamouris, M., Ding, L., Fiorito, F., Oldfield, P., Osmond, P., Paolini, R., Prasad, D. \& Synnefa, A.J.S.E. (2017). Passive and active cooling for the outdoor built environment-Analysis and assessment of the cooling potential of mitigation technologies using performance data from 220 large scale projects. Solar Energy, 154, 14-33. https://doi.org/10.1016/j.solener.2016.12.006

Sosa, M.B. (2017). Estrategias de mitigación de la isla de calor, sustentabilidad ambiental y eficiencia energética de perfiles urbanos de baja densidad en zonas áridas. [Heat island mitigation strategies. Environmental sustainability and energy efficiency of low-density urban profiles in arid zones]. Salta, Argentina: National University of Salta. (in Spanish with English summary).

Sosa, M.B., Correa, E.N. \& Cantón, M.Al. (2018). Neighborhood designs for low-density social housing energy efficiency: Case study of an arid city in Argentina. Energy \& Buildings, 168. 137-146. https://doi.org/10.1016/j.enbuild.2018.03.006

Stocco, S. (2016). Impacto de la morfología y materialidad de las plazas en las condiciones energéticoambientales en ciudades de clima árido. [Impact of the morphology and materiality of squares on the energy-environmental quality of cities located in arid zones]. Mendoza: Universidad Tecnológica Nacional. (in Spanish with English summary).

Stocco, S., Cantón, M.A., \& Correa, E. (2020) Evaluation of design schemes for urban squares in arid climate cities, Mendoza, Argentina. Building Simulation, 14, 763-777. https://doi.org/10.1007/s12273020-0691-5

Synnefa, A., Dandou, A., Santamouris, M., Tombrou, M., \& Soulakellis, N. (2008). On the Use of Cool Materials as a Heat Island Mitigation Strategy. Journal of Applied Meteorology and Climatology, 47(11), 2846-2856. DOI: 10.1175/2008JAMC1830.1

Synnefa, A., Saliari, M., \& Santamouris M. (2012). Experimental and numerical assessment of the impact of increased roof reflectance on a school building in Athens. Energy and Buildings, 55, 7-15. https:// doi.org/10.1016/j.enbuild.2012.01.044

Tsoka, S., Tsikaloudaki, A., \& Theodosiou, T. (2018). Analyzing the ENVI-met microclimate model's performance and assessing cool materials and urban vegetation applications-A review. Sustainable Cities and Society, 43, 55-76. https://doi. org/10.1016/j.scs.2018.08.009

Tumini, I., \& Higueras, E. (2012). Alcance y limitaciones de las herramientas de simulación para el estudio del microclima urbano. [Scope and limitations of the simulation tools for the study of the urban microclimate]. DYNA Energía y Sostenibilidad, 2, 1-17. DOI: http://dx.doi.org/10.6036/ES6921

Tumini, I., \& Pérez Fargallo, A. (2015). Aplicación de los sistemas adaptativos para la evaluación del confort térmico en espacios abiertos, en Madrid. [Application of adaptive systems for the evaluation of thermal comfort in open spaces, in Madrid]. Hábitat Sustentable, 5(2), 57-67. http://revistas.ubiobio. cl/index.php/RHS/article/view/1933. (in Spanish with English summary).

UN-Habitat World Cities Report (2016). Urbanization and development: emerging futures.

Wang, Y., \& Akbari, H. (2016). Analysis of urban heat island phenomenon and mitigation solutions evaluation for Montreal. Sustainable Cities and Society, 26, 438-446. https://doi.org/10.1016/j. scs.2016.04.015

Weather Underground (2017). Retrieved from https:// espanol. wunderground.com/

Yamamoto, Y. (2006). Measures to mitigate urban heat islands. Science and Technology Trends. Quarterly Review, 18(1), 65- 83. https://www.coolrooftoolkit. org/wp-content/uploads/2012/04/Measures-toMitigate-UHI-Yamamoto.pdf

Yang, X., Zhao, L., Bruse, M., y Meng, Q. (2012). An integrated simulation method for building energy performance assessment in urban environments. Energy and Building 54, 243-251. doi: 10.1016/j.enbuild.2012.07.042

Yucekaya, M., \& Uslu, C. (2020). An analytical model proposal to design urban open spaces in balance with climate: A case study of Gaziantep. 
Land Use Policy, 95(4),104564. 10.1016/j.landusepol.2020.104564

Zhou, B., Rybski, D., \& Kropp, J. P. (2017). The role of city size and urban form in the surface urban heat island. Sci Reports, 7, 4791. https://doi.org/10.1038/ s41598-017-04242-

Zinzi, M., \& Agnoli, S. (2012). Cool and green roofs. An energy and comfort comparison between passive cooling and mitigation urban heat island tech- niques for residential buildings in the Mediterranean region. Energy and Buildings, 55, 66-76. https:// doi.org/10.1016/j.enbuild.2011.09.024

Zinzi, M., Carnielo, E., \& Agnolic, S. (2012). Characterization and assessment of cool coloured solar protection devices for Mediterranean residential buildings application. Energy and Buildings, 50, 111119. https://doi.org/10.1016/j.enbuild.2012.03.031 